\title{
A CRITIQUE OF BANGLADESHI ADOPTION OF BASEL TYPE CAPITAL REGULATION: AN INSTITUTIONAL VIEW
}

\author{
A KM Kamrul HaSan ${ }^{1}$, YASUShi SuZUKi ${ }^{2}$
}

Abstract

\begin{abstract}
International concern on bank capital and minimum capital adequacy was first raised in 1980, in the G-10 countries governors meeting at the Bank for International Settlements (BIS) to respond to a series of bank failures and financial instability observed in Western developed economies. Later, the Basel Committee on Banking Supervision (BCBS) of the BIS proposed the Basel accord I, II and III in 1988, 2004 and 2010, respectively. Bangladesh Bank (BB) has introduced the 'capital to risk weighted assets'-based approach for assessing the capital adequacy of banks in 1996 and later formally introduced the Basel framework in the early 2000s for its regulated banks. However, during Basel accord II and III implementation period (2009-2018), the banking industry accumulated huge non-performing loans which eroded its profitability. This creates a skepticism regarding any loopholes within the institutions. This paper argues that the naïve and excess reliance on External Credit Assessment Institutions (ECAls') credit rating in the process of adopting the Basel-type capital adequacy amounted to a risky strategy for the Bangladeshi banking industry in a sense that ECAls allocate less efforts on accumulation of credit risk screening skills. We also document that the huge transaction cost and high coupon rate embedded within the debt instrument like the subordinated debt (sub-debt) issued by the regulated banks as Tier 2 capital might shrink the bank's profitability and its contribution to the national exchequer. Little in the existing literature has been addressed to investigate the adoption of Basel regulations in Bangladesh from the institutional lens. This paper critically reviewed the Bangladeshi ECAls regulations and sub-debt regulations to fill this research gap.
\end{abstract}

JEL classification: E58, K20, K23

Keywords: BCBS, Basel accord, ECAls regulation, Sub-debt regulation 


\section{INTRODUCTION}

The Basel framework was first introduced in 1988 by the Bank for International Settlements (BIS) as a regulatory tool to respond to frequent bank failure in the western economies in the 1980s (Davis, 1995; Goodhart, 2011). On the other hand, to maintain the financial stability and to protect public interest, Bangladesh Bank (BB) has introduced several prudential banking regulations in recent decades. The Basel-type risk-based capital adequacy framework (hereafter, the Basel accord) was one of them. BB has introduced the 'capital to risk weighted assets' based approach for assessing the capital adequacy of banks, having abandoned the 'capital to liabilities' approach in 1996 (BB, 2002) whereas, Basel accord II and III were formally introduced in 2009 and 2015 , respectively (BB, 2010, 2014). However, a significant deterioration of asset quality as well as overall fragility of the financial sector has created a 'lost decade' (20092018) in the banking sector. For instance, the country's non-performing loans (NPL) to total loans and advances ratio stood at 10.3 percent as of December 2018 whereas the shortfall of loan loss provisions was BDT 66.1 billion during the same period (BB, 2018)(see annex 1 for banking sector ROA, ROE and NPL in the past decade). The situation became worse in 2019; when the NPL ratio reached 11.99 percent which amounted to BDT 1.16 trillion in levels, and the shortfall of loans loss provisioning stood at BDT 81.3 billion (BB, 2019). Consequently, the share of the banking sector's contribution to the country's Gross Domestic Product (GDP) dropped to 7.38 per cent in FY 2018-19 from 12.98 percent in FY 2010-11 (see annex 2 showing financial sector inputs to GDP in the past decade).The vulnerability of the banking sector seems to adversely downgrade the country's financial stability. For instance, BB has prepared the overall financial stability index of the country considering three sub-indices (i) Banking Soundness Index (BSI), (ii) Financial Vulnerability Index (FVI), (iii) Regional Economic Climate Index (RECI) which are shown in Figure 1. We can see that the financial stability of the county deteriorating over the years. It is apparent that the resilience of the financial sector and its financial stability have deteriorated in this 'lost decade' despite adoption of the Basel accord.

Additionally, in November 2019, several newspapers reported that the 'High Court', the highest court of legal system of the country, ordered BB to form immediately a nine-member committee of experts of the banking sector to dig out the loopholes in the existing regulations to identify the reasons for the defaulted loans (H C Clears, 2019). In turn, the government has decided to form a stateowned asset management company (named 'Bangladesh Asset Management Corporation') for recovery and management of the financial sector's NPL (MoF, 2020). What is more, to blunt the recent coronavirus (COVID-19) shock in the economy, IMF Asia Pacific deputy director and prominent economist Anne-Marie Gulde-Wolf has commented that, "reforming the banking sector is one

Figure 1: Composite Financial Stability Index

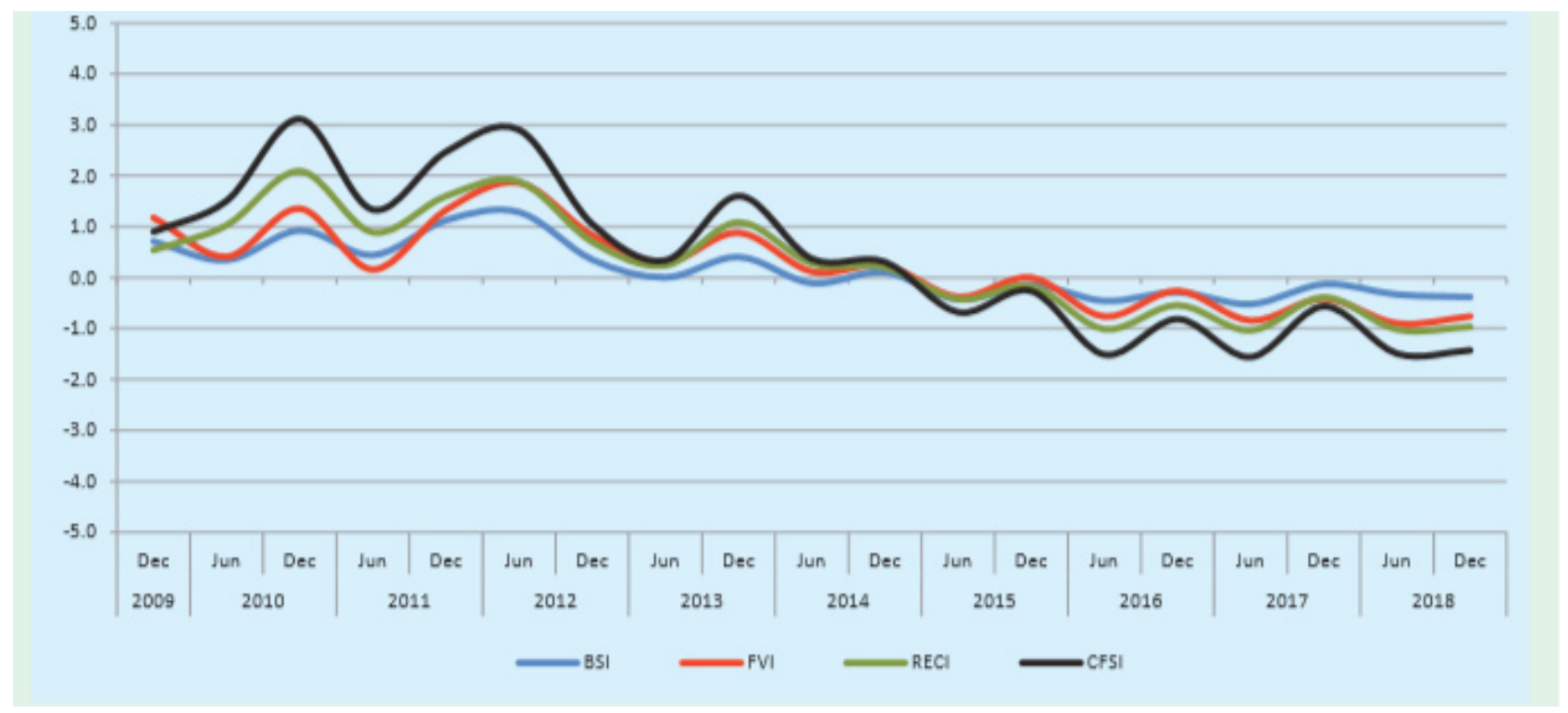

Source: $B B, 2018, p p .48-49$ 
of the top priorities for the Bangladesh government to enhance the resilience of the economy. Efficient financial resource allocation with an effective banking sector would help accelerate the recovery from the COVID-19 shock, and restore the robust growth momentum" (Anas, 2020). Apparently, the poor performance of the banking sector becomes a major concern not only for the academics but also for the judicial service, policy makers and professional economists. Based on the above-mentioned realities of the Bangladeshi banking industry, the study raises the following research question: why have micro prudential regulation like the Basel accord failed to fix the banking sector malaise?

This study hypothesized that the Basel framework has given Bangladeshi banks an ill-incentive in their credit risk management, leading to the huge accumulation of NPL. This hypothesis is drawn from the contributions by the 'Regulation' school of economics including Freixas, Leven and Peydró (2015) analyzing the relationship between the systemic risk in banking and the micro-prudential regulations. Also, this study applies an institutional approach to understanding how the Basel regulations as formal institutions (rules) have been structured in the Bangladeshi banking sector leaving the ECAls to allocate less resources on credit risk screening skills, consequently deteriorating the overall outcomes of the rules. Besides, we analyse the subordinated debt regulation from a transaction cost perspective to quantify the issuance cost of sub-debt and to locate the real opportunity cost of the issuance of sub-debt. Little in the academic debate has been addressed to shed an analytical light on the impact of Basel regulations on the Bangladeshi banking sector as one of the root causes of banking sector malaise.

The method adopted by the study is in-depth institutional analysis of the existing regulations. As the regulations on ECAls and sub-debt are closely interrelated in the Basel accord implementation process in Bangladesh, we critically analyze those regulations from an institutional perspective. Specifically, how well the credit risk quantification is conducted in the Basel framework and how well the homogenization of credit risk screening works in Bangladesh as well as what is the institutional cost/transaction cost involved in the issuance of sub-debt.

The paper proceeds as follows. Section two discusses neo-institutional economists' view on the role of regulations to understand the role the Basel accord has in the banking sector. In section three, we discussed on the methodologies of the study. Section four describes the approaches which are used in computation of Riskweighted assets(RWA) for credit risk under the Basel accord from a Bangladesh perspective and also discusses the main attributes of sub-debt regulations. Section five describes the institutional analysis of the regulations of ECAls and sub-debt in Bangladesh. Section six contains concluding remarks and policy implications.

\section{LITERATURE REVIEW ON REGULATION AND SUB-DEBT}

Economic theory of regulation can be categorized from two perspectives: public interest view and private interest view (Peláez \& Peláez, 2009). According to Peláez \& Peláez (2009) public interest view governments should interfere in market regulation for the greater welfare of society whereas a private interest view shares doubts about the effectiveness of such initiatives on market power (p. 4). Some researchers advocate for regulation to reduce the effect of externalities (Coase, 1960). Some are favored to reduce 'information asymmetries' in the market. For instance, 'market for lemons' (Akerlof, 1970) and 'credit rationing' (Stiglitz \& Weiss, 1978) are widely used terms to explain information asymmetries in the credit market. Scholars argue that three important disciplines underpin the regulation such as (a) a well-designed institution which promotes responsibility and accountability, (b) a fiduciary legal system and (c) behavioral aspects of economic systems (Davis, Lukomnik \& Pitt-Watson, 2016). As the Basel framework is a micro prudential banking regulation, we summarize the neo-institutional economists' view on regulation to aid our discussion in upcoming sections.

\section{NeO-institutional ECONOMists' View ON REGULATION: INSTITUTIONAL STRUCTURE AND TRANSACTION COST PERSPECTIVE}

Langlois (1986a, b) categorized the contributions of neo-institutional economics into three main points: (a) transaction cost and property rights, inspired by Coase (1937) and further extended by Williamson $(1979,1985)$; North (1990) (b) shed light on commons, based on Hayek (1948) and further explained by Ostrom (2005) (c) analyzing innovation (Schumpeter, 1926, 1934, 1942) and the economic agent (Alchian, 1950) which is extended as evolutionary theory by Nelson \& Winter (1982). In addition, Scott (2014) mentioned four influential neo- 
institutional economic theories that contributed more to conceptualization of institutions in economics such as (a) transaction cost economics (b) game-theoretic approaches (c) evolutionary economics theory (4) resource-based theory. He (Scott, 2014), mentioned three pillars of institutions namely the regulative pillar, normative pillar and cultural-cognitive pillar; and put institutional economists' views of institutions on the 'regulatory pillar' (p.60). It is not possible here to discuss all the theories and approaches of neo-institutional economics, but we focus on Douglass North's view (as he analyses the institutions and institutional change in more coherent ways) to facilitate our analysis on 'institutional structure' of Basel regulation.

Prominent institutional economist and Noble laureate Douglass North stressed rules as systems and enforcement mechanisms in his analysis (Scott, 2014). For example, "institutions are a set of rules, compliance procedures, and moral and ethical behavioral norms designed to constrain the behavior of individuals in the interests of maximizing the wealth or utility of principals" (North, 1981, pp. 201212). Terming the institution as "the rules of the game in a society" (North, 1990, p. 3); he specified that institutions provide the structure of cost of production which is the combination of transformation cost (typically land, labor and capital) and transaction cost (cost of property rights). Here he elaborates on the transaction cost concept of Williamson (1985). North (1990) further argued that institutions are made up of formal rules (for example political and judicial rules, economic rules and contract) and informal rules (for example, code of conduct, norms of behavior and conventions) (pp.36-47). Any changes in the formal rules should be compatible with the informal rules which exist in the society or organization and the incentives provided to enforce rules are essential to make an efficient institution (pp. 137-140). He argued, in the absence of such 'incentives for institutions'; the outcome of implementing any rules in the society is insignificant. As an economic historian, North $(1981,2005)$ opined that without developing effective institutions or existence of an adaptive society the regulation became ineffective. That is, 'institutional structure' is the prerequisite for optimum efficiency from institutions as North (2005) viewed it. Ostrom (1993); herself also a Noble laureate in economics in 2009, mentioned that the institutional arrangements and incentive can limit the rent seeking behavior of the civil servants and large landowners in host countries. However, such an approach of institutional analysis has some weaknesses and is criticized by contemporary economists. For instance, Suzuki (2011) while referring to the Knight (1992) discussion on 'cost minimization standard' in the transaction cost theory mentioned that such a style of institutional analysis is often misleading; and raises at least three factors as exception to the standards: (a) hidden benefits that are not readily apparent (b) formal external constraints (i.e. the interest of the state); and (c) uncertainty as a result of which economic agents may not create the least costly rules because they lack either the capacity or the knowledge to establish them (p.45).

The neo-institutional economists apply transaction cost theory to explain the institutions and institutional structure and argue that institutional change aims to reduce transaction cost. In this context the 'transaction cost analysis' concept is widely accepted by the neoinstitutional economists. Williamson (1985) categorized transaction cost into two, ex ante and ex post. Ex ante costs are the costs of drafting, negotiating and safeguarding an agreement to avoid complexities and contingencies involved with a contract (Williamson, 1985, p. 20). These costs ensure the acceptance of a contract among related parties as Williamson (1985) mentioned, "Exante inter firm safeguards can sometimes be fashioned to signal credible commitments and restore integrity to a transaction" ( $p$. 20). On the other hand ex post costs of a contract may arise from four corners such as (a) the mal adaptation cost incurred when transactions drift out of alignment, (b) the haggling cost that is incurred to correct ex post misalignments (c) setup and running costs associated with the governance structures to which disputes are referred and (d) the bonding cost of effecting secure commitments (p.21).

In summary, neo-institutional economic theory (accordingtoNorthandWilliamson)showsthatinstitutional efficiency depends on 'institutional structure' and 'transaction cost' for institutions and organizations. While introducing institutions in the economic organization, we should take into consideration the 'institutional structure' and 'transaction cost' otherwise the expected result might not be obtained from adoption of institutions in the organization. In this study we chiefly analyses the Basel accord (from the context of Bangladesh) through these two institutional lenses. 


\section{METHODOLOGIES}

This paper follows a descriptive methodology to investigate the research question. While involved in institutional analysis of the regulations, we take into consideration BB's guidelines on the Basel accord instead of the main text of the Basel framework ${ }^{2}$. We shall note that while in quantification of the credit risk of the banking exposure, BB has adopted the Basel accord ${ }^{3}$ under standardised approach (SA) and under this approach, the Basel framework (BCBS, 2019) and BB $(2010,2014)$ acknowledged the external credit assessment institutions (ECAIs) rating notch while in computation of credit risk. Therefore, the methods include the discussion on the various provision in the ECAls regulation to examine the ECAls credit risk quantification structure and public disclosure of ECAls to explore how ECAI regulations matter in banking sector performance. On the other hand, while in discussion on the regulations of subordinated debt we focus on transaction cost and coupon rate of debt. As was discussed earlier, transaction cost is one of the conventional dogmas in institutional analysis. Hence, our methodologies attempt to shed light on sub-debt regulations to investigate the actual transaction cost involved in issuance of sub-debt. In a nutshell, to explore the research question, we keep the ECAl regulations in one hand and sub-debt regulations in another as a methodology of this study.

\section{REgULATIONS UNDER THE BASEL ACCORD IN BANGLADESH}

\section{Regulations of EXTERNAL CREDit ASSESSMENT INSTITUTIONS (ECAIS)}

$B C B S$ in assessment of credit risk under the SA in Basel II, Basel III advocates ECAls rating for assigning risk weights under this approach (BCBS, 2006, 2017). BB has recognized ECAls credit rating categories with BB's rating grade for computing capital requirements for credit risk (BB, 2010, 2014). Therefore, ECAls are playing an important role of assessing credit risk of exposure in favor of $\mathrm{BB}$ which

\footnotetext{
${ }^{2}$ See the full and latest version of the main text of Basel Framework of BCBS. https://www.bis.org/basel_framework/index.htm?m=3\%7C14\%7C697

${ }^{3}$ See the Basel accord II and III implementation related all guidelines and notifications of Bangladesh Bank https://www.bb.org.bd/mediaroom/ baselii/baselll.php
}

hopes to bring harmonization of credit risk among banks and finally the asset quality of the banking industry will be improved. This study hence assumes that ECAls play the role of 'quasi regulator' while rating an entity/ loan exposure of a bank, as, the central bank has authorized ECAls for exposure rating which is used for calculating a bank's overall RWA under the SA. While regulating the CRAs in Bangladesh, there are two legal institutions such as (a) CRC rule $1996^{4}$ issued by Bangladesh Securities and Exchange Commission (BSEC) and (b) 'Guidelines for Recognition of Eligible ECAls-2008' issued by BB). In fact, the BSEC first issued licenses to Credit Rating Companies (CRC) in 2002 under CRC rules 1996 and BB recognized the first ECAls in April 2009. In the next sub-sections, we will briefly discuss the various attributes of these two institutions which aims to aid our discussion in section 5 .

\section{Attributes of Credit rating companies (Crc) RULES-1996}

CRC rules consists of 16 Articles within the four chapters and we will focus on the key points of these rules which are related with computation of the Risk Based Capital Adequacy (RBCA) framework (Basel accord) to keep our discussion relevant and on track.

Chapter I describes the definition of the terms used in the rule and the date of adopting the rules. According to the rules, "Credit Rating Company" means an investment advisor company which intends to engage in or is so engaged primarily in the business of evaluation of credit or investment risk through a recognized and formal process of assigning a rating to present or proposed loan obligations or equity of any business enterprise" (BSEC, 1996, Article 2(d)). Chapter II presents the regulations of business. For example, it refers that to get registration as a Credit Rating Company (CRC), the CRC should be incorporated as a public limited company under the Companies Act, 1994 and must have a paid-up capital of at least five million (Article 4(b)). Regarding competence, the CRC has to be a joint venture technical collaboration with a reputed credit rating company (Article 4(c)). However, detailed of scope of business for such collaboration is not specified in the institutions which makes the article pointless. The minimum requirement of professional staff in a CRC is two persons with two years professional experience in credit

${ }^{4}$ See the main text at theBangladesh Securities and Exchange Commission (BSEC) web portal.https://www.sec.gov.bd/home/lbookor https://www. sec.gov.bd/Ibook/F-03_2015.pdf 


\section{Table 1: Key points of Article 9 in relevance to the Basel accord}

\begin{tabular}{|c|c|c|}
\hline SI no. & Code of conduct & Relevant sub-clause \\
\hline 1 & Quality of rating process & $\begin{array}{l}\text { - Establish a rating methodology for each industry or each type of instrument and } \\
\text { disclose it to the public website. Review of the methodologies and model at least } \\
\text { once a year by Rating Committee of CRC. } \\
\text { - There should be a Rating Committee (RC) of each CRC with five members including } \\
\text { two senior analysts. RC is the final authority to assign the rating. } \\
\text { - The Internal Review Committee (IRC) shall double check the documents and } \\
\text { information on which the rating team made their rating. The rating team consists } \\
\text { of at least two analysts. }\end{array}$ \\
\hline 2 & Monitoring and updating & $\begin{array}{l}\text { - There are two types of rating, initial rating and surveillance rating. For entity } \\
\text { rating the surveillance rating must be for at least the next three years after the } \\
\text { initial rating and for issue of instrument rating the surveillance rating must be for } \\
\text { the lifetime of the instrument after the initial rating. However, if any part (either } \\
\text { CRC or client) wants to terminate the contract, they need to get permission from } \\
\text { the BSEC. }\end{array}$ \\
\hline 3 & Integrity of rating process & $\begin{array}{l}\text { - CRC should establish an ethical standard and code of conduct for its employees } \\
\text { and disclose it on their website. }\end{array}$ \\
\hline 4 & $\begin{array}{l}\text { CRC independence and } \\
\text { avoidance of conflict of } \\
\text { interest }\end{array}$ & $\begin{array}{l}\text { - Directors and shareholders should not interfere over the activities and decisions } \\
\text { of RC. } \\
\text { - CRC cannot rate any entity which has any relation with CRC or its director. } \\
\text { - There is a required declaration by the directors of CRC and CEO and affidavit by } \\
\text { employees of CRC to avoid conflict of interest and ensure independence. }\end{array}$ \\
\hline 5 & CRC procedures and policies & $\begin{array}{l}\text { - If any CRC's receive } 10 \text { percent or more of its annual revenue from a single entity } \\
\text { or group, it should be publicly disclosed. }\end{array}$ \\
\hline 6 & $\begin{array}{l}\text { CRC analysts and employee } \\
\text { independence }\end{array}$ & $\begin{array}{l}\text { - Employees remuneration cannot be linked with the clients whom analysts' rate } \\
\text { or CRCs shall not share any revenue with analysts except service benefits. Analysts } \\
\text { are also prohibited from doing marketing, or receiving negotiation fees. } \\
\text { - Any CRC or its employee cannot buy or sell or engage in any transaction with } \\
\text { listed securities. }\end{array}$ \\
\hline 7 & $\begin{array}{l}\text { CRC responsibility to the } \\
\text { investing public and issuers }\end{array}$ & $\begin{array}{l}\text { - CRC shall publish the list of updated ratings on its website. } \\
\text { - It should publish the historical default rate. }\end{array}$ \\
\hline 8 & Disclosures of these rules & $\begin{array}{l}\text { - CEO of the CRC should submit a declaration after every rating report that it has } \\
\text { rated the entity while complying with all rules described in CRC rules } 1996 \text {. }\end{array}$ \\
\hline
\end{tabular}

Source: BSEC,1996, Article 9

rating or investment advisory activities (Article 4(f)).

Chapter III, Article 9, describes the detailed operational procedures of CRC. There are eight broad code of conducts which are described in this clause and the CRC are asked to adopt, publish and follow these codes. We summarized the key points of each code in Table 1 for our further discussion in the rest of the chapter.

Finally, Chapter IV describes the inspection and investigation of a CRC by BSEC if deemed necessary.

\section{ATTRIBUTES OF GUIDELINES FOR RECOGNITION OF ELIGIBLE ECAIS 2008 (BB,2008)}

${ }^{4}$ See the full text athttps://www.bb.org.bd/mediaroom/baselii/basellı. php
The Banking Regulation and Policy Department (BRPD) of BB issued its first circular on September 23, 2008 regarding "Guidelines for recognition of eligible External Credit Assessment Institutions (ECAls)" which came into effect from January 2009. The guidelines (BB, 2008) referred to six general clauses while recognizing ECAls and these are: (a) recognition criteria, (b) mapping process, (c) application process, (d) on-going recognition, (e) guidelines to banks regarding nomination of ECAls and (f) general instruction.

\section{(a) Recognition criteria}

The guideline mentioned six major criteria such as objectivity, independence, international access/ transparency, disclosure, resources and credibility for determining the recognition of ECAls. There are a number 
Table 2: List of criteria for recognition as ECAI

\begin{tabular}{|c|c|c|}
\hline SI no. & Criteria & Sub-content of the criteria \\
\hline \multirow{7}{*}{1} & \multirow{7}{*}{ Objectivity } & (a) Manuscript of methodology \\
\hline & & (b) Internal process \\
\hline & & (c) Rating scale and their sensitivity \\
\hline & & (d) Validation system \\
\hline & & (e) Ongoing review \\
\hline & & (f) Data base management \\
\hline & & (g) System back testing \\
\hline \multirow{6}{*}{2} & \multirow{6}{*}{ Independence } & (a) Registration system with SEC \\
\hline & & (b) Ownership quality \\
\hline & & (c) Procedure to ensure independence \\
\hline & & (d) Board members influence on rating activities \\
\hline & & (e) Solvency of the company \\
\hline & & (f) Schedule of credit assessment fees \\
\hline \multirow{4}{*}{3} & \multirow{4}{*}{ Transparency/International access } & (a) International exposure \\
\hline & & (b) Accessibility of the ECAls rating \\
\hline & & (c) Availability of assessment methodology \\
\hline & & (d) Nature of rating \\
\hline \multirow{4}{*}{4} & \multirow{4}{*}{ Disclosure } & (a) Definition of default rating category \\
\hline & & (b) Actual transition rate towards default rating \\
\hline & & (c) Disclosure of transition matrix \\
\hline & & (d) Code of conduct \\
\hline \multirow{6}{*}{5} & \multirow{6}{*}{ Resources } & (a) Capital structure and net worth \\
\hline & & (b) Hard and soft infrastructure \\
\hline & & (c) Number of professional staffs \\
\hline & & (d) Personal policy \\
\hline & & (e) Internal work relationship \\
\hline & & (f) Data warehousing \\
\hline \multirow{4}{*}{6} & \multirow{4}{*}{ Credibility } & (a) Degree of acceptance by the client \\
\hline & & (b) Market share of ECAI \\
\hline & & (c) Handling conflict of interest \\
\hline & & (d) Market penetration approach \\
\hline
\end{tabular}

Source: BB, 2008

of sub - content items in each criterion which are shown in Table 2.

\section{(b) Mapping process}

BB will evaluate and bring harmony among the ECAls rating notch through numerals one to six Cumulative Default Rate (CDR) and the short term rating is used for short term lending whereas, the long term rating is used for long term lending (BB, 2008). BB considers CDR as a quantitative factor to evaluate an ECAls' rating category. The transition of an individual notch towards the default category observed in a particular ECAl category will be compared to the standards available domestically/ regionally/internationally (BB, 2008). On the other hand, the qualitative factors are not disclosed in the guidelines and it is stated that it will be set by BB's working group.

\section{(c) Application process}

To become an eligible ECAI, the CRC must be registered under CRC Rule, 1996 of BSEC. This means that any credit rating company either domestic or international must get a license from BSEC. 


\section{(d) Ongoing recognition}

This clause mention that the BB is responsible for the monitoring and supervision of ECAls. The recognition of the BB will be reviewed annually, and BB can derecognize any ECAl if it seems necessary. However, the author confirmed with the BB's public disclosure that so far, no ECAI has been derecognized/delisted by BB since 2009 .

(e) Guidelines to Banks

Banks can nominate the ECAls for credit rating of banking book exposures and notify the BB regarding their nomination of ECAls and banks can use the ratings of nominated ECAls for a reasonable period (p.5).

\section{(f) Compliance instruction to ECAls}

Three general compliance instructions are referred to in the guidelines for the ECAls. These are: (a) ECAls should submit their quarterly rating report to the $B B$, (b) there should be a unique pricing system among ECAls and (c) all ECAls will follow the IOSCO/BSEC code of conduct for CRC (p. 5).

In section 5, we critically evaluate the abovementioned provisions in the ECAls' regulations to explore our main research question.

\section{REGULATIONS OF SUB-DEBT IN BANGLADESH}

Before starting our main discussion on sub-debt regulations in Bangladesh, we should note that sub-debt was first used as regulatory capital (RC) by US commercial banks when the capital adequacy ratio of major US banks were dropping sharply in the 1960s (see Goodhart, 2011) and it is recognized as a constituent of RC by BCBS in the Basel accord in 1988 (BCBS, 1988). In academic circles there is contemporary debate on the role of sub-debt in capital regulation. Scholars advocate for inclusion of subdebt as RC, hoping that the debt yield could bring 'direct market discipline' (see Evanoff, 1994; Evanoff \& Wall, 2000, 2001, 2002; Evanoff et al., 2011; Garten, 1986). Their point is that a distressed bank needs to collect costly debt instruments (like sub-debt) with a high risk premium from the market, hence market force will control bank managers' risk appetite. In addition, it is expected that sub-debt yield could provide a signal to the regulators regarding a bank's capital requirement and resilience of the capital which apparently enhances the off-site supervision of the banking authority (Ahmed, 2009). However, such a 'direct and indirect' market discipline thesis (see BCBS, 2003) was challenged by other contemporary scholars and views that sub-debt yield couldn't control banks' risk taking behavior (see Brown, Evangelou \& Stix, 2017; Götz \& Tröger, 2016; Rixtel, González \& Yang, 2015). Besides, some have argued that sub-debt yield provides a weak signal to the regulator (Miller, Olson \& Yeager, 2015). On top of that, the regulatory uses of sub-debt could tap the regulated banks into the 'sub-debt trap' and could create a neo-systemic risk in the entire financial system (Hasan, 2020). The logic is when Common Equity Tier 1 capital (CET 1) is not sufficient to maintain minimum capital-to-risk weighted assets ratio (CRAR), the capitaldeficient banks(banks having inadequate capital) will rely on issuance of sub-debt (as Tier 2 capital) to maintain the regulatory capital and; if most of the banks in the industry are adopting such a strategy, it creates a bubble and neo-systemic risk (Hasan, 2020). However, to keep our discussion on track, we focus our discussion on institutional analysis of sub-debt regulations from the transaction cost perspective.

In principle, there are two legal documents in Bangladesh that banks need to follow while issuing subdebt as Tier 2 capital under the Basel framework. These are (a) Guidelines on Subordinated Debt (BRPD circular no. 13, dated October 14, 2009) and (b) Securities and Exchange Commission (Private Placement of Debt Securities) Rules, 2012 (SEC notification October 29, 2012). Below we summarize the key features in both legal documents to aid the critical institutional analysis in Section 5.

\section{BB'S GUIDELINES ON SUB-DEBT (BB, 2009, 2014)}

Bangladesh Bank recognized sub-debt as Tier 2 and Tier 3 capital components (see BB, 2002, 2009, 2010) whereas, it is considered as Tier 2 capital components under Basel III guidelines and a few amendments made in the existing guidelines on subordinated debt 2009 (BB, 2014, pp. 85-93). A debt instrument which has no maturity date and redemption period (i.e. perpetual subordinated debt), is considered to be Additional Tier 1 (AT 1) and which has fixed maturity date and redemption period (i.e. not perpetual in nature) is considered as Tier 2 capital (BB, 2014). At the time of writing (June 2020), there is only one (1) debt instrument which has been considered as AT 1 among all sub-debts issued by banks and in this study subdebt refers to the debt instruments which are considered as Tier 2 capital under the Basel accord III guideline. We shall note that when issuing sub-debt, banks firstly need BSEC consent, then the application documents along with 
the consent of BSEC have to be submitted to BB for final consent. The key features of the guidelines for sub-debt are as follows.

a) "Subordinated debt will be referred to the debt instrument which will be subordinated to deposits and other liabilities of the bank. It implies that the claims of the subordinated debt holders will be junior to the claims of the depositors and the other creditors" (BB, 2014, p. 88). "In the event of liquidation or winding up of the issuers business and distribution of return on investment, the bondholders will be ranked after claims of the depositors and other creditors i.e. it will be ranked immediately ahead of ordinary shareholders" (BB, 2014, p. 89).

b) The tenure of the debt is at least 5 years and the amortization of the debt will be 20 percent annually during the last five years of the bond's life. In general, the majority of sub-debt is 7 years.

c) As it is not a deposit in nature, it is hence not included in the deposit insurance scheme.

d) Sub-debt will be unsecured but supported by an 'agreement of trust'/trust deed.

e) The maximum ceiling of subordinate debt was 30 percent of the amount of Tier 1 capital (BB, 2009), however it is again stated that Tier 2 capital should be 4 percent of the total RWA or 88.89 percent of CET 1, whichever is higher (BB, 2014, p. 9, 88).

f) The amortization of the debt will be 20 annually during the last five years.

g) There should be an agreement with managers to the issue/lead arranger and underwriter of the issue (BB, 2014, p. 90).

h) While in application for issuing the debt, banks should submit a copy of the subordinated note format and agreement and amortization schedule along with all salient features of the debt (BB, 2009, 2014).

\section{Securities and exchange Commission (PRIVATE PLACEMENT OF DEBT SECURITIES) RULES, $2012^{6}$ (BSEC, 2012)}

BSEC has adopted the rules in 2012 for the interest of the capital market and it applies for issuance of debt securities through private placement. As the sub-debt is offered through private placement the rules are considered a bible for issuance of sub-debt. We summarize below the

${ }^{6}$ Full text available at https://www.sec.gov.bd/home/laws key points of the rules that are related to subordinated debt.

(a) Definition

BB (2009) mentioned that subordinated debt would be 'unsecured' and the term is explained by the rules in the following way, "unsecured debt instrument means debt securities, in which the issuer owes the holders an indebtedness and which is secured by claims over all present and future assets of the issuer subsequent to all secured lenders/eligible investors" (Article 1(t)).

(b) Role of CRC

The issue needs to be rated initially by any credit rating company (CRC) and its periodical surveillance rating shall be done by the said rating company till the full and final redemption or conversion of the debt instrument (Article 3(3)).

\section{(c) Role of Trustee}

Article 9 of the regulation provides that there should be a trustee (registered trustee by BSEC) of the issue which is appointed by the issuer and a registered 'Deed of Trust' (as per schedule C of the rules) should be executed between trustee and issuer which explain the rights and obligations of both parties. The details of trustee registration, duties and responsibilities of trustee are described in Article 9. In addition, duties of the trustee in case of default of the issue are described in Article 12 . What is more, the trustee annually reports to the BSEC regarding the instrument, interest payment and other relevant information. BSEC has rights to change the trustee in the event of securities holders claim or in the public interest, if suitable (Article 9 (5)(i)).

(d) Fees

BSEC consent fees @ 0.10 percent of the face value of the securities have to be paid by the issuer within 15 days of issuance of a consent letter (Article 7 (1)) and annual maximum trustee fee is 0.25 percent of the outstanding amount of the securities to be paid by the issuer (Article 9 (10)). This cost can be considered a transaction cost.

\section{(e) Information Memorandum (IM)}

Article 4 (o) recognized that the IM of the issue that is prepared by the issuer should contain all relevant information about the issuer, issue and the trustee. Format and contents of such an IM are described in the schedule $B$ of the rules. However, the missing point is that there is no obligation to publish the IM to the general public or shareholders although they are the stakeholders of the 
sub-debt issued under the Basel framework.

Therefore, from the above discussion, it is evident that sub-debt is intended to be issued to strengthen regulatory capital, needs both BSEC and BB consent, and the trustee plays a vital role in this context. A reasonable question which might arise in the reader's mind (from the literature review in Section 2) by both rules is, how costly is the sub-debt? What is the opportunity cost of issuance of sub-debt? In the next section, we discuss these issues.

\section{CRITICAL VIEWS ON REGULATIONS OF BASEL FRAMEWORK IN BANGLADESH}

\section{Critical ReView on eCAis Regulations}

From the previous discussion in Section 4, it is evident that the main lacuna in CRC rules 1996 is that the rules do not explain the specific punitive measures against a CRC, rather, Article 16 states that under the SEC ordinance, 1969, the commission can take appropriate action based on the inspection or investigation report. What is 'appropriate' is really a subjective matter. Interestingly, the BB guidelines mentioned criteria for ECAls recognition but don't put any ceiling on the minimum or disclosed any standard against these criteria. For example, regarding the ECAls internal process, the rules mentioned that ECAls must disclose their analysis team, rating committee and internal verification system while filing for recognition but not disclose the minimum requirement or any benchmark regarding those yardsticks. Although the 'transparency' and 'disclosure' parts are incredibly significant issues for ECAls, in the mentioned rules there are no specific instructions which creates some room for ECAls to skip the quality disclosure. The author, while checking the websites of the eight credit rating agencies of the country at the time of writing, found there is little disclosure on the default rating and transition matrix. Additionally, in the 'Resources' and 'Credibility' sections, there is no specific requirement or standard requirement prescribed by $\mathrm{BB}$. As a result, whatever is written in the rules, the recognition process seems unclear and ambiguous to the general public and academics. It seems that there is a gap in the 'rules in books' and the 'rules in practice'.

In short, we critically assess the ECAls regulation to investigate the following two issues in the institutions: (a) how well do the institutions clarify the accumulation of credit risk screening skills of ECAls for exposure rating (b) is the disclosure of an ECAI sufficient to ensure its credit risk screening skills?

\section{ECAIS ACCUMULATION OF CREDIT SCREENING SKILLS}

We examine ECAls regulations in how it dictates the ECAls to accumulate credit screening skill i.e. how well institutions put pressure on the ECAls to allocate resources to accumulating credit risk screening skills. Firstly, although there is no specific regulation described in the rules for the internal rating procedure of ECAls, each ECAl has developed their own rating procedure under the rules (BSEC, 1996, Article 9; BB 2014, p.126). Based on the methodologies disclosed on the public websites regarding rating bank exposure, it has been observed that the process of the bank exposure rating has six steps such as initial rating agreement, collecting information through rating analysts, preparation of a draft report and getting feedback from firms, placing the rating reports before the rating committee, assigning a final rating and conducting an annual surveillance rating. Therefore, to prepare a quality report ECAls must put enough effort (in terms of sufficient time and skilled analysts) into the accumulation of credit screening skills. However, only two professional employees are mandatory to run a CRC (BSEC 1996, Article 4(f)) and BB in its ECAls recognition guideline has instructed all ECAls to follow a 'uniform pricing policy'(BB, 2014, Section 3.1 (b)). As a result, there is no option to charge high prices for any individual ECAls which demotivates them from employing skilled and experienced analysts for rating purposes. Besides, there is cutthroat competition (Bangladesh has eight ECAls) among ECAls which discourages them from allocating resources to accumulate credit risk screening skills. This seemingly is a 'convoy' system by BB while controlling the remuneration of ECAl rating, however, it distorts the capacity (as ECAI has no option to increase revenue by pricing strategy) of ECAls to hire more professionals in credit analysis, resulting in lowering the overall quality of credit ratings. Surprisingly, BB in the same guidelines, has placed all ECAl's ratings in the same category in the sense that there is no grading based on an ECAl's 'reputation' or 'quality of rating'. As a result, ECAls have lost another incentive to employ a highly paid analyst to confirm a perfect rating and hence competition couldn't help them to build 'reputational capital'. The 'convoy system' by BB in incubating ECAls in the same pace and direction may have created an ill-incentive, rather we may say, a moral 
hazard effect for ECAls to shirk monitoring, resulting in free-riding on the protected profit margin without making an effort to build their reputational capital. To conclude, we presume that thinner profit margins under severe competition may discourage ECAls from improving the quality of credit information and market forces cannot correct the ECAl's rating quality. Such loopholes in the ECAls institutional structure distort their incentive for accumulation of credit risk screening skills.

Secondly, under CRC rules 1996, a CRC is a public limited company and hence will follow the Companies Act 1994 while appointing directors. However, as a CRC is not a listed public limited company, it need not follow the corporate governance code that BSEC published in 2006 (latest amendment in 2018) while appointing a board of directors. Hence all the directors on the board of CRCS are shareholders and directors, no independent directors are appointed as board members. The total number of members on the board of directors and RC of each CRC is shown in annex3. Annex 3 shows that one CRA doesn't disclose its board of directors' names whereas forty percent of CRAs don't disclose their RC members number and the details of RC members expertise on the public website. In short, we can say that ECAl's governance do not have to follow the corporate governance code of BSEC and hence do not publish their full internal governance structure to the public. It is mentioned in the rules that a "credit rating shall be assigned by rating committee and not by any individual analysts" (BSEC, 1996, Article 9 (1)). The serious missing point in the said rules is that there are no specific requirements, responsibility or remuneration system described explicitly for external members of a rating committee. These issues are not addressed in the BB guidelines either. Therefore, this undisclosed and unexplained information by both regulatory bodies and CRAs, is creating ambiguity or making a 'rating process black box' (Cifuentes, 2008) for understanding the true governance structure of an ECAI. In a word, from an institutional perspective ECAls feel no pressure to follow corporate governance codes and they maintain a weak governance structure which adversely affects their accumulation of credit information skills in a transparent and accountable way.

\section{INSUFFICIENT PUBLIC DISCLOSURE OF ECAI}

It is apparent that the disclosure requirement that is obligatory in the ECAls regulation is not enough to protect public interest or enhance the resilience of the banking system. To illustrate, under CRC Rules 1996, there are two types of disclosures that a CRC must publish. One is a disclosure within the rating deed (between CRC and a firm) and another is a public disclosure on several issues on their website. In order to make the rating agreement free from potential biases, the rules suggest disclosing the compensation arrangement with rating clients (BSEC, 1996, Article 9,(5)(b), p.113)). In the case of a public disclosure the CRC shall disclose the entity or group identity if it receives a significant percentage (10 percent or more) of revenue from a single group/entity and in addition, its director's shareholding position of listed securities on a half yearly basis (Article 9). The rules also made it compulsory to publish the updated rating of entities and the methodologies of the rating, as well as the historical default rating. At the time of writing, we checked on all the ECAI official web portals regarding this public disclosure; we did not find the public disclosures in full as these rules prescribed. As BSEC provides the license to CRAs for public interest (BSEC,1996), it is the responsibility of BSEC to monitor the CRAs compliance to protect public interest. Whereas in BB guidelines, only the pricing system of ECAls needs to be disclosed to the public and, the minimum methodology for rating corporate clients are described with five risk and sub-risk categories such as financial risk, business/industry risk, management risk, security risk and relationship risk. But there is no specific weight on each risk assigned by central bank guidelines. As a result, there is no disclosure from ECAls regarding how they assigned the rating to a specific exposure based on this risk. Therefore, both general investors and banks are simply knowing the rating notch of an exposure without its full disclosure.

Therefore, it is evident that the existing regulations for ECAls in Bangladesh are providing a legal scope to skip the material disclosure. Although BSEC and BB acknowledged the existing institutional lapses in their recent reports, neither supervisor took any visible initiative to resolve them. In our view, such insufficient disclosure creates a grey zone for banks, researchers, and all other stakeholders to put trust in ECAI's exposure ratings and it is a supervisory responsibility to clear such grey zones from the ECAl's disclosure. 


\section{Critical ReView of SUb-DebT Regulation From AN INSTITUTIONAL COST PERSPECTIVE}

From the previous discussions in Section 4 we have observed that there are two types of costs involved with sub-debt such as (a) transaction cost/issue cost of subdebt (b) coupon rate of sub-debt. Below we analyse such costs with empirical illustrations.

\section{TransaCtion COST/ISSUANCE COST OF SUB-DEBT}

As sub-debt is a financial contract, are there any transaction costs for sub-debt from an institutional perspective? If so, what are they? Chowdhury (2019) identified several transaction costs for bond issuance in Bangladesh such as bond registration fees (consent fees of BSEC), stamp duties, annual trustee fees, and ancillary charges. However, based on the definition of transaction cost by Williamson (1985) and the mentioned issue of the cost of sub-debt in the said two legal documents, we identified some potential transaction costs of sub-debt which are shown in Table 3.

From Table 3, it seems that some ex ante costs such as consent fees and trustee fees are fixed by regulators and some costs such as mandated lead arranger (MLA) fees, legal fees and other costs may be dependent on the bank's negotiation strategy. However, ex post costs such as administrative costs seem to be variable costs. We shall note that all sub-debts are subscribed through private placement and not listed in the bourses (except MPB of IBBL). Hence there is a scarcity of publicly available IM. However, we have collected three information memorandums of sub-debt that were issued in 2014

Table 3: Transaction cost/ issuance cost of sub-debt in Bangladesh

\begin{tabular}{|c|c|c|}
\hline SI no. & Ex ante cost & Ex post cost \\
\hline 1 & $\begin{array}{l}\text { Consent fees to BSEC which are } 0.10 \text { percent of } \\
\text { the total face value (BSEC, 2012, Article 7). }\end{array}$ & \\
\hline 2 & $\begin{array}{l}\text { Initial trustee fee which is } 0.25 \text { percent of the } \\
\text { outstanding amount of the debt securities } \\
\text { (BSEC, 2012, Article 9). }\end{array}$ & Annual trustee fee \\
\hline 3 & $\begin{array}{l}\text { Issue manager/Mandated Lead arranger fee (it } \\
\text { depends on the agreement). }\end{array}$ & Any other administrative cost related with post-issue matters. \\
\hline 4 & Legal counsel fee. & - \\
\hline 5 & Initial rating fees paid to credit rating agencies. & Surveillance rating fee throughout the life of the instrument. \\
\hline 6 & $\begin{array}{c}\text { Printing and advertisement cost or any other } \\
\text { expenses. }\end{array}$ & \\
\hline
\end{tabular}

Source: see BB, 2009, 2010,2014; BSEC, 2012

Table 4: Ex-ante transaction cost and coupon rate of three sub-debts issued in 2014 (Amount in BDT million)

\begin{tabular}{|c|c|c|c|c|}
\hline SI no. & Details & ABBL* & MBL* & SIBL* \\
\hline 1 & Total issue amount & 2,500 & 3,000 & 3,000 \\
\hline 2 & $\begin{array}{c}\text { Rate of return/Coupon } \\
\text { rate }\end{array}$ & 11 percent-13 percent & $\begin{array}{c}\text { 6-month FDR rate + margin } \\
3 \text { percent }\end{array}$ & $\begin{array}{c}120 \text { percent of } 180 \text { days } \\
\text { MTD rate }\end{array}$ \\
\hline 3 & $\begin{array}{c}\text { Consent fees to BSEC ( } 0.10 \\
\text { percent of the total face } \\
\text { value) }\end{array}$ & 2.5 & 3.0 & 3.0 \\
\hline 4 & $\begin{array}{l}\text { Trustee fee, rating fees, } \\
\text { arrangement fees, legal } \\
\text { counsel fees, stamp fees, } \\
\text { etc. }\end{array}$ & 37.91 & 30.47 & 21.21 \\
\hline 5 & $\begin{array}{l}\text { Total transaction cost (ex } \\
\text { ante) (sl no. } 3+4)\end{array}$ & 40.41 & 33.47 & 24.21 \\
\hline 6 & $\begin{array}{l}\text { Percentage(\%) to total } \\
\text { issue amount(sl. no } 5 \div 1 \text { ) }\end{array}$ & 1.62 & 1.12 & 0.81 \\
\hline
\end{tabular}

Source: Information Memorandum of the related SD, excerpts of IM attached in the annexure 
Table 5: Total ex ante transaction cost for subordinated debt issued for capital adequacy purposes (amount in USD million)

\begin{tabular}{|c|c|c|}
\hline Year & Amount of sub-debt issue** & Ex-ante cost (@1.00 percent) \\
\hline $2009 *$ & 123 & 1.2 \\
\hline 2010 & 98 & 1.0 \\
\hline 2011 & 44 & 0.4 \\
\hline 2012 & 45 & 0.5 \\
\hline 2013 & 98 & 1.0 \\
\hline 2014 & 315 & 3.2 \\
\hline 2015 & 243 & 2.4 \\
\hline 2016 & 474 & 4.7 \\
\hline 2017 & 676 & 6.8 \\
\hline 2018 & 904 & 9.0 \\
\hline Total & 3,020 & 30.2 \\
\hline
\end{tabular}

Note: *2009 data included the MPB of IBBL, ** as per average exchange rate shown in annex 4

by three different banks. Based on the information memorandums, the ex ante transaction cost of each issue is presented in Table 4.

Table 4 shows that ex ante costs are on average, 1.18 percent for three issues. On the other hand, the ex post transaction costs are trustee fees which are around 0.05 percent of the face value of the issue and the surveillance rating fees which are BDT 0.3 million per year (it depends on the outstanding amount of the debt). As information memorandums of other banks are not available to the public, the author cannot compute the transaction costs of individual banks. Anyway, if we consider the transaction cost (ex ante) is one(1) percent on average of the sub-debt issued by the banks, we can compute the real amount of transaction cost of sub-debt. In Table 5 we estimate the total ex ante transaction cost of sub-debt since 2009 that banks have had to incur to issue sub-debt as Tier 2 capital.

Table 5 shows that total ex ante transaction cost for issuance of sub-debt over the last 10 years is approximately USD 30 million. In addition, fixed annual trustee fees, rating fees and other administrative expenses have to be paid by issuer banks as ex post transaction costs during the tenure of the bond. It also evident that BSEC had earned USD 3.02 million (i.e. 3,022 $\times 0.1 \%$ ) during the period 2009 to 2018 from the banks while providing consent to issue sub-debt which is exclusively used only for bank's capital adequacy purposes.

In fact, the real cost of issuance of sub-debt is much higher than our estimated figures as BB in its report mentioned that "issuing costs (trustee fee, arranger fee, legal counseling fee, credit rating fee, consent fee, trust deed registration cost, issue management/corporate advisory fee, stamp duty and post issue management fee) and secondary transaction costs (annual depository/ listing fee, transaction fee, new issue fee) that amount to nearly 6 percent of issue size" (BB, 2019b; p.28). The crux question here is: who had finally paid such high transaction costs? In fact, banks recorded the sub-debt related costs under the headings of 'operating expenses' in the financial statements. We presume that bank operating profit has adversely impacted such costs and the national exchequer has finally paid the price for the transaction cost. Hence, we view that this institutional cost of issuance of sub-debt is a by-product of ill-designed regulations by Bangladeshi regulators.

\section{COUPON RATE OF SUB-DEBT}

Table 4 shows that the offer rate of the return/coupon rate is higher than the 6-month fixed deposit rate. The reader may ask, why do banks offer such a high coupon rate against the sub-debt? We presume that there are two reasons that motivate banks to collect high cost bearing debt instruments such as sub-debt from the market. First, when banks keenly need sub-debt to maintain their capital ratio, there is competition among banks to offer high interest rates to sell their debts. It is rational that issuers obviously want to sell their debt in the full amount and offer a lucrative interest rate to the institutional investors which is higher than the other deposit products on the market. Second, as the debt is unsecured, not included in the deposit insurance scheme and not unlisted in the 
burses, issuers provide some 'risk premium' to the debt holders. In practice, the coupon rate is calculated based on the weighted average fixed deposit rate in the market (for 180 days) plus a fixed risk premium offered by individual banks.

The missing point in the aforementioned rules (BB, 2009, 2014; BSEC, 2012) is that it has neither offered any fixed ceiling on coupon rate of the sub-debt nor any methodology offered by the central bank while fixing a coupon rate which creates an opportunity for the banks to offer a high rate to sell their debt instrument. In addition, we have searched all bank's published annual reports to seek the 'interest paid against subordinated debt' however, the data is not shown separately, rather most of the banks are merging their 'interest paid on subordinate debt' with 'interest paid on deposits and borrowing' in the published financial statement. As a result, we presume that the general shareholders/investors are not aware of the real 'coupon rate' of sub-debt issued by their banks which erode the profitability of the bank. In our view this is the opportunity cost of sub-debt which is overlooked in the existing regulations.

\section{CONCLUDING REMARKS AND POLICY IMPLICATIONS}

In the beginning of this paper, we raised the research question as to why the Basel framework has failed to fix the banking sector malaise in Bangladesh. We discussed the ECAls regulation and sub-debt regulation in detail to answer the question. We argued that the standardized approach of the Basel accord advocates the reliance on ECAls rating for credit risk. However, homogenization of credit risk while relying on ECAls credit information has not had a positive impact on asset quality in Bangladesh. As evidence, we examined the ECAls regulations in Bangladesh and found that within the institutional structure' there are no 'incentives' for ECAls while accumulation of credit risk screening skills and the provision in the regulations on disclosure is not sufficient to ensure reliance on ECAl credit rating methodology. Second, there is no incentive-based regulation introduced by the supervisors when regulating ECAIs (i.e. there is no 'rating over ECAls rating' by regulators which evaluate the rating quality on one hand and ECAls remuneration control by BB on the other hand). In turn ECAls have accumulated less credit screening skills which makes futile the adoption of SA by the central bank. Regarding sub-debt regulations, we observed that national supervisors (BB and BSEC) have issued two important regulations regarding issuance of sub-debt as Tier 2 capital and despite high transaction cost/issue cost and coupon rate, banks are frequently issuing sub-debt chiefly to maintain minimum CRAR. We have found evidence that there is a huge cost embedded with sub-debt which is initially incurred by the issuing bank and finally the shareholders and the national exchequer have to pay the price. However, the existing regulations failed to well address these issues.

Our findings have at least two policy implications. First and foremost, we have found that ECAls lack of effort on credit screening skills, poor internal governance structure, and lack of incentive-based regulation contribute to lower quality of ECAls credit information and ultimately distort the objective of the Basel accord. Although quantifying of the credit risk is the main responsibility of ECAls under the standardized approach of the Basel accord, to check the efficiency of the 'institutional structure' is the prime responsibility of the regulator (BB, 2014). Thus, our results are suggestive of an immediate institutional reform in the ECAls institution to ensure that they allocate their resources on credit risk screening skills which hopefully would have positive impact while improving asset quality of the banks. Side by side, bank managers cannot forgo their credit risk management responsibility as banks exists in society as an expert in credit risk screening and monitoring. If only ECAls are doing this job, then the bank becomes a redundant economic institution. The authors hope that the central bank will consider this issue more prudently and consider introducing some room for IRB side by side with SA.

Second, our analyses reinforce the arguments that naïvely relying on sub-debt (despite their high transaction cost and coupon rate) shrinks bank profitability as well as the national exchequer stake on bank profit. Hence, either the policy makers fix the transaction cost (by necessary amendments in the institutions of sub-debt) and put a rate cap on sub-debt (otherwise ask the bank to collect the sub-debt subscription through a public offering instead of private placement)or impose restriction on cash dividends for shareholders and bonuses for managers aiming to build up retained earnings as well as CET 1 capital. 


\section{REFERENCES}

Ahmed, M.K. (2009). The Role of an Explicit Subordinated Debt Policy in the Smooth Transition to Basel II: Developing Economy Perspective. Journal of Banking Regulation, 10(3), 221-233.

Akerlof, G.A. (1970). The Market for „Lemons”: Quality Uncertainty and the Market Mechanism. The Quarterly Journal of Economics, 84(3), 488-500.

Alchian, A.A. (1950). Uncertainty, Evolution, and Economic Theory. Journal of Political Economy, 58(3), $211-221$.

Anas, A.Z.M. (2020, April 20). Fixing Banking Sector Key to Blunting Coronavirus Shock: IMF Asia Pacific deputy chief tells FE. The Financial Express, p. 8,7. Retrieved from: https://today.thefinancialexpress.com.bd/last-page/fixing-bankingsector-key-to-blunting-coronavirus-shock-1587318407.

Bangladesh Bank (BB), (2002). Master Circular on Capital Adequacy of Banks (BRPD circular no. 10, 24 November 2002 ). Dhaka, Bangladesh: Banking Regulation and Policy Department, Bangladesh Bank.

Bangladesh Bank (BB), (2008). Guidelines for Recognition of Eligible External Credit Assessment Institutions (ECAIs) (BRPD circular no. 7, September 23, 2008). Dhaka, Bangladesh: Banking Regulation and Policy Department, Bangladesh Bank.

Bangladesh Bank (BB), (2010). Revised Guidelines on Risk Based Capital Adequacy (RBCA) for Banks(BRPD circular no. 24, August 3, 2010). Dhaka, Bangladesh: Banking Regulation and Policy Department, Bangladesh Bank.

Bangladesh Bank (BB), (2014). Guidelines on Risk Based Capital Adequacy (Revised Regulatory Capital Framework for banks in line with Basel III) (BRPD circular no. 18, December 21, 2014). Dhaka, Bangladesh: Banking Regulation and Policy Department, Bangladesh Bank.

Bangladesh Bank (BB), (2018). Financial Stability Report, 2018, Issue 9. Dhaka, Bangladesh: Financial Stability Department, Bangladesh Bank. https://www.bb.org.bd/pub/index.php.

Bangladesh Bank (BB), (2019). Bangladesh Bank Quarterly, July-September 2019, Volume XVII, No.1. Dhaka, Bangladesh: Bangladesh Bank.

Bangladesh Bank (BB), (2019b). Comprehensive Framework on the Development of the Bond Market in Bangladesh. Dhaka, Bangladesh: Bangladesh Bank. Retrieved from: https://www.bb.org.bd/pub/publictn.php.

Bangladesh Securities and Exchange Commission (BSEC), (1996). Credit rating Companies Rules. 1996. Dhaka, Bangladesh: BSEC. Retrieved from: https://www.sec.gov.bd/home/lbook.

Bangladesh Securities and Exchange Commission (BSEC). (2012). Securities and Exchange Commission (Private Placement of Debt Securities) Rules, 2012. Dhaka, Bangladesh: BSEC. Retrieved from: https://www.sec.gov.bd/home/laws

Basel Committee on Banking Supervision (BCBS) (1988). International Convergence of Capital Measurement and Capital Standards. Basle, Switzerland: Bank for International Settlements. Retrieved from: https://www.bis.org/publ/ bcbs04a.htm

Basel Committee on Banking Supervision (BCBS), (2003). Markets for Bank Subordinated Debt and Equity in Basel Committee Member Countries. Basel, Switzerland: Bank for International Settlements.

Basel Committee on Banking Supervision (BCBS), (2006). International Convergence of Capital Measurement and Capital Standards A Revised Framework Comprehensive Version. Basel, Switzerland: Bank for International Settlements. Retrieved from: https://www.bis.org/publ/bcbs128.htm

Basel Committee on Banking Supervision (BCBS), (2017). Basel III: Finalising post-crisis reforms. Basel, Switzerland: Bank for International Settlements. Retrieved from: https://www.bis.org/bcbs/publ/d424.pdf

Basel Committee on Banking Supervision (BCBS), (2019). The Basel Framework. Basel, Switzerland: Bank for International Settlements.

Brown, M., Evangelou, I., Stix, H. (2017). Banking Crises, Bail-ins and Money Holdings (working paper no.2017-2). Cyprus: Central Bank of Cyprus. Retrieved from: https://www.centralbank.cy/en/publications/working-papers.

Chowdhury, S.K. (2019, July 3). Long-term Finance and Bond Market Development in Bangladesh. The Daily Financial Express, p. 4.

Coase, R.H. (1937). The Nature of the Firm. Economica, 4(16), 386-405.

Coase, R.H. (1960). The Problem of Social Cost. Journal of Law and Economics, 3(October), 1- 44. 
Davis, E.P. (1995). Debt Financial Fragility and Systemic Risk. Oxford: Oxford University Press.

Davis, S., Lukomnik, J., Pitt-Watson, D. (2016). What They Do With Your Money. New Heaven and London: Yale University Press.

Evanoff, D.D. (1994). Capital Requirements and Bank Regulatory Reforms. In C. A. Stone \& A. Zissu (Eds.), Global Risk |Based Capital Regulation Volume 1: Capital Adequacy. New York: Irwin Professional Publishing.

Evanoff, D.D., Jagtiani, J.A., Nakata, T. (2011). Enhancing Market Discipline in Banking: The role of Subordinated Debt in Financial Regulatory Reform. Journal of Economics and Business, 63, 1-22.

Evanoff. D.D., Wall, L.D. (2000). Subordinated Debt as Bank Capital: A Proposal for Regulatory Reform (WP 2000-07). Chicago: Federal Reserve Bank of Chicago.

Evanoff, D.D., Wall, L.D. (2001). Sub-debt Yields Spreads as Bank Risk Measures. Subordinated Debt as Bank Capital: A Proposal for Regulatory Reform. Journal of Financial Services Research, 20(2/3), 121-145.

Evanoff. D.D., Wall, L.D. (2002). Measures of the Riskiness of Banking Organizations: Subordinated Debt Yields, Riskbased Capital, and Examination Ratings. Journal of Banking \& Finance, 26, 989-1009.

Freixas, X., Leven, L., Peydró, J-L. (2015). Systemic Risk, Crises, and Macroprudential Regulation. Cambridge, MA: The MIT Press.

Garten, H.A. (1986). Banking on the Market: Relying on Depositors to Control Bank Risks. Yale Journal on Regulation, $4(1), 129-172$.

Goodhart, C. (2011). The Basel Committee on banking Supervision: A History of the Early Years 1974-1997.Central Bank and the Financial System. Cambridge, England: Cambridge University Press.

Götz, M.R., Tröger, T.H. (2016). Should the Marketing of Subordinated Debt be Restricted/different in One Way or the Other? What to do in the Case of Mis-selling? Brussels, Belgium: Economic and Monetary Affairs Committee, European Union.

Hasan, A.K.M.K. (2020). An Institutional Approach to Understanding the Impact of Capital Regulation (The Basel Framework) on Bangladeshi Banking Industry: A Critique of Multiple Institutional Failures (Doctoral dissertation, Ritsumeikan Asia Pacific University, Oita, Japan). Retrieved from: http://en.apu.ac.jp/media/library/thesis/index. html/ (will be publicly available on 2021)

Hayek, F.A. (1948). Individualism and Economic Order. Chicago, USA: University of Chicago Press.

HC clears (2019, November 4). HC Clears BB's Spl Facility for Defaulters. The Financial Express, p(s).1,3.

Defaulters get more times to reschedule loans with $2 \%$ down payment. Dhaka Tribune, p.1.

Defaulters must make 15 pc down payment. The Daily Star, p(s).1,11.

Knight, J. (1992). Institutions and Social Conflict. Cambridge, UK: Cambridge University Press.

Langlois, R.N. (1986a). The New Institutional Economics: an Introductory essay. In Langlois, R. (Ed.), Economics as a Process: Essays in the New Institutional Economics (pp.1-25). New York: Cambridge University Press.

Langlois, R.N. (1986b). Rationality, Institutions, and Explanation. In Langlois, R. (Ed.), Economics as a Process: Essays in the New Institutional Economics (pp. 225-255). New York: Cambridge University Press.

Millers, S., Olson, E., Yeager, T.J. (2015). The Relative Contributions of Equity and Subordinated Debt Signals as Predictors of Bank Distress During the Financial Crisis. Journal of Financial Stability, 16, 118-137.

Ministry of Finance (MoF), (2020). Draft BAMCO Act 2020. Dhaka, Bangladesh: Financial Institutions Division, Ministry of Finance, Government of the people's Republic of Bangladesh. Retrieved from: https://fid.gov.bd/site/view/draft_ law.

Nelson, R.R., Winter, S.G. (1982). An Evolutionary Theory of Economic Change. Cambridge, MA: Belknap Press.

North, D.C. (1981). Structure and Change in Economic History. New York, NY: W.W. Norton \& Company, Inc.

North, D.C. (1990). Institutions, Institutional Change and Economic Performance. Cambridge, UK: Cambridge University Press.

North, D. C. (2005). Understanding the Process of Economic Change. Princeton, NJ, USA: Princeton University Press.

Ostrom, E. (2005). Understanding Institutional Diversity. Princeton, NJ, USA: Princeton University Press.

Peláez, C.M., Peláez, C.A. (2009). Regulation of Banks and Finance: Theory and Policy after the Credit Crisis. Hampshire, England: Palgrave Macmillan. 
Rixtel, A.V., González, L.R., Yang, J. (2015). The Determinants of Long-term Debt Issuance by European Banks: Evidence of Two Crises (BIS working papers No. 513). Basel, Switzerland: Bank for International Settlements.

Schumpeter, J.A. (1926). Theorie der wirtschaftlichen Entwicklung (2nd Ed.) München und Leipzig: Duncker \& Humblot. Schumpeter, J.A. (1934). The Theory of Economic Development: An Inquiry into Profits, Capital, Credit, Interest, and the Business Cycle. Cambridge, MA: Harvard University Press.

Schumpeter, J.A. (1942). Capitalism, Socialism and Democracy. London: Allen \& Unwin.

Scott, W.R. (2014). Institutions and Organizations: Ideas, Interests and Identities (4th Ed.). CA, USA: SAGE Publications.

Stiglitz, J.E., Weiss, A. (1981). Credit Rationing in Markets with Imperfect Information, American Economic Review, 71(3), 393-410.

Suzuki, Y. (2011). Japan's Financial Slump: Collapse of the Monitoring System under Institutional and Transitional Failures. Hampshire, England: Palgrave Macmillan.

Williamson, O.E. (1979). Transaction-Cost Economics: The Governance of Contractual Relations. Journal of Law and Economics, 22(2), 233-261.

Williamson, O.E. (1985). The Economic Institutions of Capitalism: Firms, Markets, Relational Contracting. New York, N.Y.: The Free Press. 